\title{
Giant Ragweed (Ambrosia trifida) Seed Production and Retention in Soybean and Field Margins
}

\author{
Jared J. Goplen, Craig C. Sheaffer, Roger L. Becker, Jeffrey A. Coulter, Fritz R. Breitenbach, \\ Lisa M. Behnken, Gregg A. Johnson, and Jeffrey L. Gunsolus*
}

As herbicide-resistant weed populations become increasingly problematic in crop production, alternative strategies of weed control are necessary. Giant ragweed, one of the most competitive agricultural weeds in row crops, has evolved resistance to multiple herbicide biochemical sites of action within the plant, necessitating the development of new and integrated methods of weed control. This study assessed the quantity and duration of seed retention of giant ragweed grown in soybean fields and adjacent field margins. Seed retention of giant ragweed was monitored weekly during the 2012 to 2014 harvest seasons using seed collection traps. Giant ragweed plants produced an average of 1,818 seeds per plant, with $66 \%$ being potentially viable. Giant ragweed on average began shattering hard (potentially viable) and soft (nonviable) seeds September 12 and continued through October at an average rate of 0.75 and $0.44 \%$ of total seeds per day during September and October, respectively. Giant ragweed seeds remained on the plants well into the Minnesota soybean harvest season, with an average of $80 \%$ of the total seeds being retained on October 11, when Minnesota soybean harvest was approximately $75 \%$ completed in the years of the study. These results suggest that there is a sufficient amount of time to remove escaped giant ragweed from production fields and field margins before the seeds shatter by managing weed seed dispersal before or at crop harvest. Controlling weed seed dispersal has potential to manage herbicide-resistant giant ragweed by limiting replenishment of the weed seed bank.

Nomenclature: Giant ragweed, Ambrosia trifida L. AMBTR; soybean, Glycine max (L.) Merr. Key words: Harvest weed seed control, seed production, seed retention.

\begin{abstract}
Conforme las poblaciones de malezas resistentes a herbicidas se hacen incrementalmente más problemáticas en la producción de cultivos, estrategias alternativas de control de malezas se hacen cada vez más necesarias. Ambrosia trifida, una de las malezas agrícolas más competitivas en cultivos en hileras, ha evolucionado resistencia a múltiples sitios bioquímicos de acción de herbicidas dentro de la planta, lo que ha hecho necesario el desarrollo de métodos nuevos e integrados de control de malezas. Este estudio evaluó la cantidad y duración de la retención de semilla de $A$. trifida creciendo en campos de soja y márgenes de campos adyacentes. La retención de semilla de $A$. trifida fue monitoreada semanalmente durante las temporadas de cosecha desde 2012 a 2014 usando trampas de colección de semilla. Las plantas de $A$. trifida produjeron un promedio de 1,818 semillas por planta, con una viabilidad potencial de $66 \%$. En promedio, $A$. trifida inició la dispersión de semilla dura (potencialmente viable) y suave (no-viable) el 12 de Septiembre y continuó durante Octubre, con una tasa promedio de 0.75 y $0.44 \%$ del total de semillas por día, durante Septiembre y Octubre, respectivamente. Las semillas de $A$. trifida permanecieron en las plantas hasta la temporada de cosecha de soja en Minnesota, con un promedio de $80 \%$ del total de las semillas estando retenidas al 11 de Octubre, cuando la cosecha de soja en Minnesota había sido completada al $75 \%$, en los años de este estudio. Estos resultados sugieren que existe una cantidad de tiempo suficiente para remover $A$. trifida que haya escapado al control en campos de producción y en márgenes de campos antes de que la semilla sea liberada de la planta, mediante el manejo de la dispersión de semilla de malezas antes o durante la cosecha. El controlar la dispersión de semillas de malezas tiene el potencial de manejar $A$. trifida resistente a herbicidas al limitar el suministro de nuevas semillas al banco de semillas de malezas.
\end{abstract}

\begin{abstract}
DOI: 10.1614/WT-D-15-00116.1
* First, second, third, fourth, seventh, and eighth authors: Graduate Student, Professor, Professor, Associate Professor, Associate Professor, and Professor, Department of Agronomy and Plant Genetics, University of Minnesota, 1991 Upper Buford Circle, Saint Paul, MN 55108; fifth and sixth authors: Extension Educator and Integrated Pest Management Specialist, University of Minnesota, 863 30th Avenue SE, Rochester, MN 55904. Corresponding author's E-mail: gople007@umn.edu.
\end{abstract}

As weeds throughout the midwestern United States continue to develop resistance to herbicides, there is a greater need for alternative weed control strategies, including nonchemical approaches such as crop rotation and harvest weed seed control (HWSC) (Shaner and Beckie 2014). Uncontrolled weeds in crop fields eventually produce seeds that 
shatter to the soil surface and repopulate the seed bank. Seed banks allow weeds to persist through cropping phases and extend weed infestations (Fenner 1995). During the normal harvest of grain crops, retained weed seeds enter the harvester, are separated from the grain, and distributed over the field by the chaff-spreading system of the harvester (Barroso et al. 2006; Blanco-Moreno et al. 2004; Rew et al. 1996; Shirtliffe and Entz 2005; Walsh and Powles 2007). Mechanisms targeting escaped weed seeds in the chaff fraction, such as HWSC systems, have been developed to either remove seeds via chaff carts or destroy seeds through seed destructors at crop harvest (Shirliffe and Entz 2005; Walsh et al. 2012; Walsh and Newman 2007; Walsh and Powles 2007). HWSC systems are reported to be from 60 to $99 \%$ effective in destroying seeds of various weed species (Walsh et al. 2013).

For HWSC systems to be effective, weeds need to retain seeds until crop harvest. There is evidence that a high level of seed retention occurs for many weeds, but seed retention can also be influenced by the growing environment (Shirtliffe et al. 2000, Taghizadeh et al. 2012). For example, in wheat (Triticum aestivum L.) production fields in western Australia, rigid ryegrass (Lolium rigidum Gaudin L.), wild radish (Raphanus raphanistrum L.), brome grass (Bromus spp. Roth L.), and wild oat (Avena fatua L.) retain $85,99,77$, and $84 \%$ of seeds until crop maturity, respectively (Walsh and Powles 2014). Seed retention of annual ryegrass (Lolium rigidum Gaudin L.) in Spanish wheat fields was even greater, with $96 \%$ seed retention at crop maturity (Blanco-Moreno et al. 2004).

Giant ragweed is one of the most competitive weeds infesting corn (Zea mays L.) and soybean across the midwestern United States, and has developed resistance to both acetolactate synthase (ALS) inhibitors and glyphosate (Heap 2015; Stoller et al. 1987; Webster et al. 1994). Giant ragweed seed inputs into the soil seed bank must be limited to prevent future infestations of giant ragweed, and may require a zero-weed threshold to prevent weed persistence (Norsworthy et al. 2014). A zero-weed threshold may require nonchemical strategies such as hand weeding before seeds shatter or HWSC to prevent seed bank replenishment. However, these systems require that weeds be controlled before seed production or that weeds retain seeds until crop harvest. There is no information on giant ragweed seed production and retention as a factor in late-season weed control strategies for the growing conditions and cropping systems of the midwestern United States. The objectives of this research were to determine: (1) the quantity of seeds produced during the growing season and (2) the level of seed retention through crop harvest in midwestern soybean and field margins.

\section{Materials and Methods}

Site Details. Experiments were conducted at the Rosemount Research and Outreach Center near Rosemount, $\mathrm{MN}\left(44.71^{\circ} \mathrm{N}, 93.12^{\circ} \mathrm{W}\right)$ in 2012 to 2014 and near Rochester, $\mathrm{MN}\left(43.91^{\circ} \mathrm{N}, 92.56^{\circ} \mathrm{W}\right)$ in 2014 (Table 1). The soil at Rosemount was a Waukegan silt loam (fine-silty over sandy or sandyskeletal, mixed, superactive, mesic Typic Hapludolls) and at Rochester was a Port Byron silt loam (fine-silty, mixed, superactive, mesic Typic Hapludolls). Weather data, including daily minimum and maximum air temperature, precipitation, wind speed, and frost dates, were obtained from the National Weather Service station nearest each site. Growing degree days (GDD) were calculated using Equation 1, where $T_{\max }$ is the maximum daily temperature, $T_{\min }$ is the minimum daily temperature, $b_{0}$ is the base temperature $(10 \mathrm{C})$, and $S_{1}$ and $\mathrm{S}_{2}$ are months indicated in Table 1.

$$
\mathrm{GDD}=\sum_{\mathrm{S}_{1}}^{\mathrm{S}_{2}} \frac{\left(T_{\max }-T_{\min }\right)}{2}-b_{0} .
$$

Giant ragweed seed retention was monitored weekly during September and October each year. Both research sites had known populations of glyphosateresistant giant ragweed. Additionally, giant ragweed at the Rochester, MN site had resistance to ALS inhibitors. Resident populations of giant ragweed plants were randomly selected each year in mid-July from a conventionally managed soybean field at both locations to monitor seed retention. Soybean were seeded at 345,947 seeds $\mathrm{ha}^{-1}$ in $76-\mathrm{cm}$ rows with commercially available varieties. At Rosemount, giant ragweed plants were also randomly selected each year in mid-July from field margins that were not actively managed for weeds, and the primary vegetation providing competition was

Goplen et al.: Giant ragweed seed retention - 247 
Table 1. Growing-season details for each year and field location that seed retention of giant ragweed was assessed for approximately $60 \mathrm{~d}$ surrounding soybean harvest at Rosemount and Rochester, MN in 2012-2014. Weather information was obtained from National Weather Service station nearest each site. ${ }^{a}$

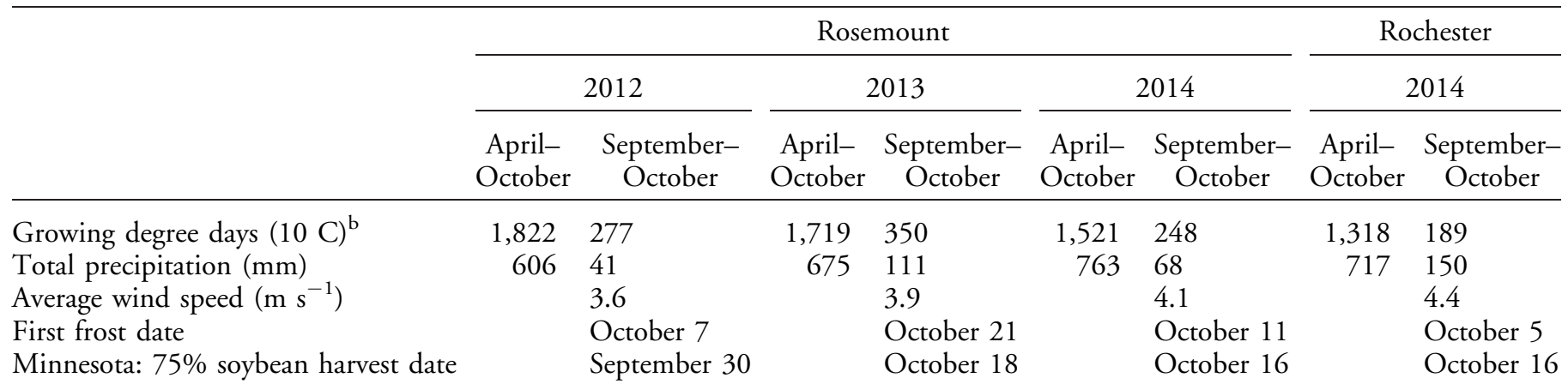

\footnotetext{
${ }^{\mathrm{a}}$ Weather data obtained from site identification: KMSP $\left(44.8831^{\circ} \mathrm{N}, 93.2289^{\circ} \mathrm{W}\right)$ for Rosemount and site identification: KRST $\left(43.9041^{\circ} \mathrm{N}, 92.4916^{\circ} \mathrm{W}\right)$ for Rochester.

${ }^{\mathrm{b}}$ Growing degree days calculated using Equation 1 (10 C base temperature).
}

smooth bromegrass (Bromus inermis L.) and giant ragweed. Giant ragweed in both field locations was allowed to compete naturally with all vegetation in the surrounding area. When traps were set up, any vegetation in the area surrounding the monitored giant ragweed plants was flattened to prevent interference with and to prevent stray seeds from falling into the seed trap.

Seed Trap Construction. Conical seed traps adapted from the gauze trap design outlined in Page et al. (2002) were installed around stems of individual giant ragweed plants to collect giant ragweed seeds. Seed traps consisted of a plastic frame formed into a 0.9-m-diam circle supporting mesh fabric funnelling to a drained plastic collection bottle $(1 \mathrm{~L})$ in the middle to capture and protect seeds from predators. Traps were placed around giant ragweed plants just below the lowest seed-producing branch, were sealed around the base of the plant using tape, and supported with fence posts.

Seed Collection. Seeds were collected weekly for 8 wk starting the first week of September through the last week of October, representing the typical time period from giant ragweed seed development to the end of soybean harvest. Traps were set up around 10 randomly selected giant ragweed plants in each field location at least $7 \mathrm{~d}$ before the monitoring period, which coincided with the seed filling period. Collected seeds were dried at room temperature (18 C) for at least $7 \mathrm{~d}$ before analysis. Seeds were separated from foreign material using an aspirator.
Apparent viability of giant ragweed seeds was determined as previously described (Ball and Miller 1989; Cardina and Sparrow 1996; Forcella 1992). To determine apparent viability, gentle pressure was applied to each seed using a forceps and seeds resisting pressure were considered potentially viable, whereas seeds being penetrated or crushed were considered nonviable. Although there are alternative methods for determining viability, apparent viability was considered adequate for the objectives of this study. Seeds from each category were counted and weighed to determine total number and average mass of seeds shattered each week.

Plant development was monitored periodically through the growing season beginning in July in 2013 and 2014 to relate giant ragweed plant development with seed production and retention. Plant height, number of primary and secondary branches, number of nodes on the primary stem, leaf number, and stages of reproductive growth were documented for the monitored plants. At the end of the monitoring period (end of October), plants were clipped at ground level, bagged, and stripped of all seeds to separate seeds from the stems. Stems were dried in a forced-air oven at $60 \mathrm{C}$ for $5 \mathrm{~d}$ to determine stem dry weight and moisture at the time of plant harvest. Since the majority of leaves were lost at the time of plant harvest, stem dry matter alone was used as a proxy for total plant dry matter. Seeds were dried and processed as previously described.

Statistical Analysis. Plant development and seed production of giant ragweed by site-year and field 
Table 2. Summary of giant ragweed seed production and plant characteristics in soybean and field margin locations in each site-year from 2012 to 2014 at Rosemount and Rochester, MN. P-values are shown for each site-year and field location combination $(n=10)$. Average columns are a weighted average of field location across all site-years.

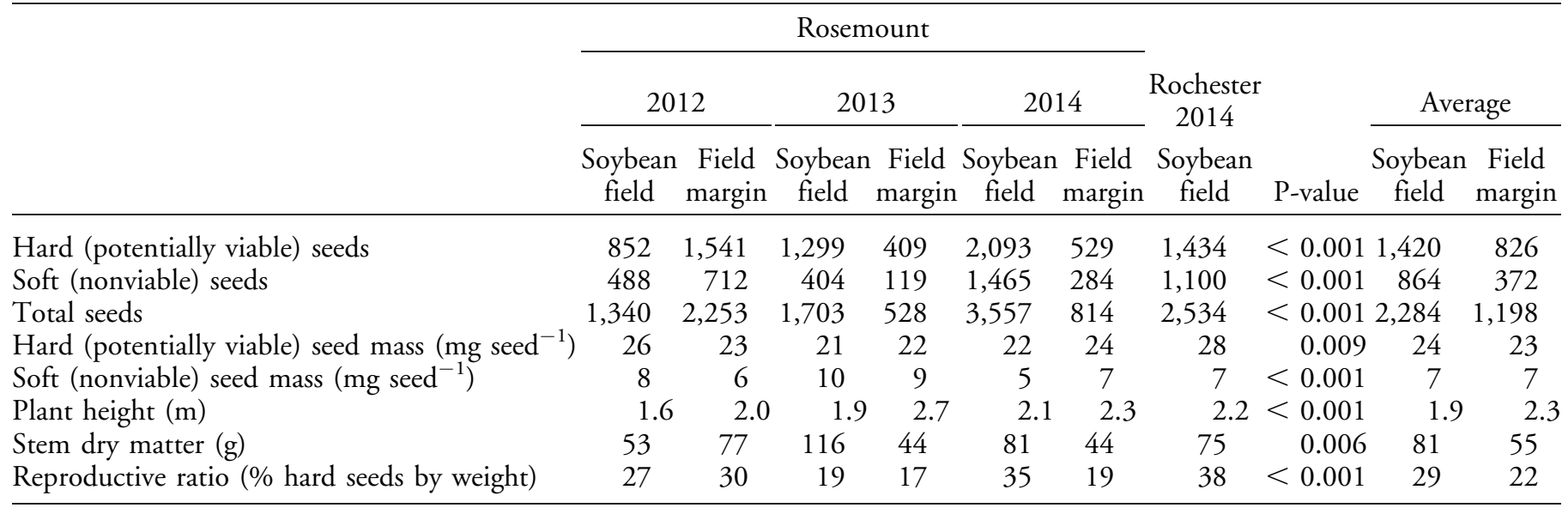

location are summarized in Table 2. To determine the effects of each site-year and field location on each plant characteristic (Table 2), an ANOVA was performed treating each site-year, field location, and their interaction as random effects. There were significant interactions between site-year and field location, so results in Table 2 represent the analysis of treating each site-year and field location combination as a unique environment. Additionally, simple and multiple linear regression analyses were performed to determine if plant development and plant physical characteristics were related to total seed production. However, total plant dry matter was the only characteristic found to be correlated with total seed production $\left(r^{2}=0.31\right.$, $\mathrm{P}<0.001)$. As a result of finding this association, total plant dry matter was included as a covariate in analysis of covariance, treating each site-year and field location combination and the covariate as random effects.

To normalize seed retention data, the number of viable and nonviable seeds retained each week was converted to a percentage of the total viable and nonviable seeds produced per plant, respectively. The relationship between percent seeds remaining and day of year was linear, and a best-fit linear regression equation (Equation 2) was fit to the normalized data (Walsh and Powles 2014), where $Y$ is the proportion of seed retention, $A$ is $100 \%$ seed retention, $B$ is the rate of seed shed $\left(\% \mathrm{~d}^{-1}\right)$, and $x$ is days after the start of seed shattering, which was predicted to be September 12 for hard (potentially viable) and soft (nonviable) seeds.

$$
Y=A+B x
$$

To determine the effects of weather and plant development on seed retention, correlation analyses were performed to relate seed retention to all plant development and physical characteristics monitored as well as precipitation, wind speed, first frost date, and GDD $(10 \mathrm{C})$. Multiple linear regression analyses were also performed to determine if a combination of weather factors affected seed retention. Although there were several weak correlations between seed retention and weather patterns, none were significant. All statistical analyses were performed using $\mathrm{R}$ version 3.1.3 (R Foundation for Statistical Computing, Wien, Austria).

\section{Results and Discussion}

Plant Development. Floral initiation of selected giant ragweed plants occurred near the end of July, but was typically delayed by several days in the more competitive field margins. Despite differences in floral initiation, pollination tended to be more uniform, and occurred in the third week of August, which was expected as giant ragweed is a short-day plant (Bassett and Crompton 1982; Mann 1942). Despite the observed variation in floral development and plant structure, there were no associations among giant ragweed reproductive development, branching characteristics, and leaf number on seed production or retention. 
There were significant effects of site-year and field location interactions on giant ragweed development (Table 2). Across all site-years and field locations, giant ragweed plants in soybean typically produced more biomass and seeds, whereas plants in field margins grew taller and had lower reproductive ratios (Table 2). These differences are typical of competition effects and are likely due to increased densities of neighboring giant ragweed and smooth bromegrass in field margins during the growing season. Consequently, giant ragweed plants in field margins may be competing for light, which causes plants to be etiolated with fewer branches, less stem biomass, and fewer leaves per plant (Jurik 1991). The result is fewer plant resources available to be allocated to seed development as reflected by the lower reproductive ratios observed in field margins (Table 2). The reproductive ratio, calculated as the percentage of hard seed biomass relative to the total stem and nonviable seed biomass, was $22 \%$ for giant ragweed plants in field margins and 29\% for plants in soybean, indicating that a larger proportion of plant biomass typically goes into seed production in a soybean field (Table 2).

Seed Production. Giant ragweed seed production varied by site-year and field location, but was largely dependent on plant size. Giant ragweed consistently produced substantial amounts of seeds each year, and demonstrated a high potential for weed seed contribution to the seed bank. Giant ragweed plants produced an average of 1,796 seeds per plant with $64 \%$ being potentially viable in $2012,1,115$ seeds per plant with $77 \%$ being potentially viable in 2013 , and 2,302 seeds per plant with $59 \%$ being potentially viable in 2014 (Table 2). These results are similar to those previously reported, in that giant ragweed typically produces 500 to 5,000 seeds per plant (Baysinger and Sims 1992; Brabham et al. 2011). The percentage of potentially viable seeds was also similar to that reported by Vitolo and Stiles (1987), who found 65\% of seeds being viable from giant ragweed grown in a soybean field. However, Harrison et al. (2001) reported only $50 \%$ giant ragweed seed viability in a cornfield. In addition to variation by site-year, seed production also varied by field location; plants in soybean produced $72 \%$ more seeds on average than plants in field margins (Table 2). The greater seed production in soybean was a result of an increase in both hard (potentially viable) and soft (nonviable) seeds. However, field location generally affected plant size, which had a direct effect on total seed production (Table 2). Over all site-years and field locations, seed production was positively correlated with aboveground plant dry matter $\left(r^{2}=0.31, \mathrm{P}<0.001\right)$, and was determined to be a significant covariate in predicting total seed production $(\mathrm{P}<0.001)$. Giant ragweed plants in field margins typically weighed less and were at higher densities than plants in soybean, typically resulting in fewer seeds being produced on plants in field margins, which is in line with what Jurik (1991) reported (Table 2). Similarly, Harrison et al. (2001) found that giant ragweed emerging $4 \mathrm{wk}$ after corn and therefore subjected to greater competition had lower overall fecundity than giant ragweed emerging simultaneously with corn.

Rate of Seed Shatter. In each site-year, giant ragweed began shattering seeds the first week of September and continued through October. It was not surprising that giant ragweed began shattering seeds at relatively the same date each year despite weather differences (Table 1), since giant ragweed is a short-day plant (Bassett and Crompton 1982; Mann 1942).

Giant ragweed seed shattering occurred at a linear rate over time, with a considerable amount of plantto-plant variation. There was no effect of field location on rate of seed retention. On average, potentially viable and nonviable seeds shattered from plants at a rate of 0.75 and $0.44 \%$ of seeds per day, respectively, beginning on September 12 (Figure 1). Harrison et al. (2001) also observed a linear rate of seed shatter over time for giant ragweed in corn, despite it being delayed in plants with delayed emergence. Similar results have been observed for other weed species in Australia, including annual ryegrass, wild radish, bromegrass, and wild oat (Walsh and Powles 2014).

The primary focus of this study was to monitor giant ragweed seed shattering through the harvest period. Consequently, seed retention was only monitored through the end of October, since soybean is typically harvested by this time in the midwestern United States. When comparing giant ragweed seed retention with typical soybean harvest dates in 2012-2014, potentially viable giant ragweed seed retention was on average $75.3 \%$ on the date when $75 \%$ of soybean were harvested in Minnesota as inferred from crop progress reports 


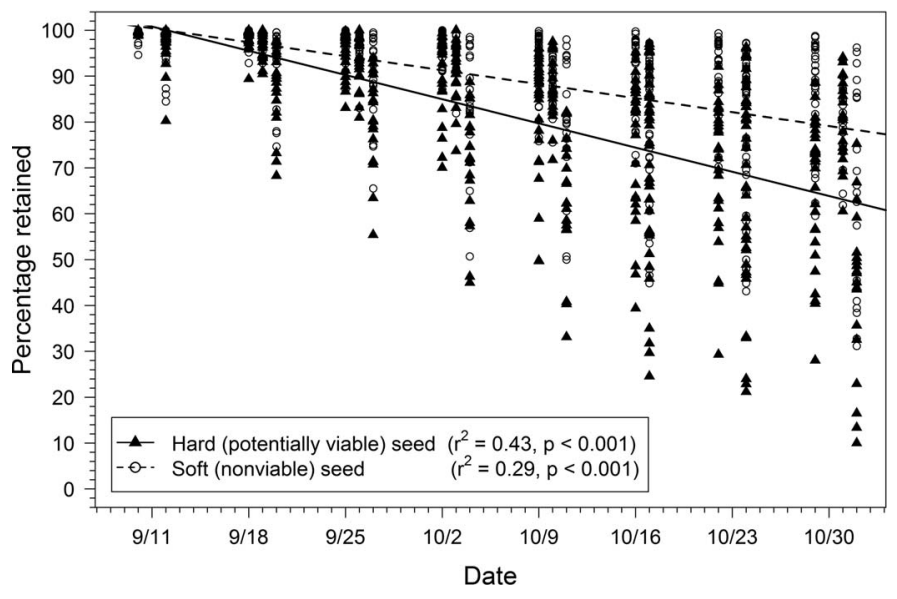

Figure 1. Hard (potentially viable) and soft (nonviable) seed retention of giant ragweed across all site-years and field locations in 2012 to 2014. Seeds began shattering on September 12 on average. Lines represent a best-fit linear model for hard $(y=100$ $-0.754 x)$ and soft seed $(y=100-0.435 x)$ retention.

(Table 1) (USDA-NASS 2014). Despite a large percentage of the seeds being retained until soybean harvest, there was large variation in the seed retention of individual plants in various site-years and field locations (Figure 1), potentially due to variation in genetic background, rate of plant development, and specific environmental conditions (Shirtliffe et al. 2000).

Weather Effects. Although individual weather events likely did affect seed retention, no correlations were observed among weather data, plant developmental characteristics, and seed retention. There was a linear association between GDD accumulation after September 1 and seed retention $\left(r^{2}=0.49, \mathrm{P}<0.001\right)$, indicating that increased GDD $(10 \mathrm{C})$ accumulation in September and October increases seed shattering. Although it was expected that seed shatter would increase after the first frost date, there were no associations between first frost dates or the number of accumulated freezing days with rates of seed shatter, likely because giant ragweed reached physiological maturity before the first frost in each year. It was expected that wind and precipitation events would increase seed shattering because of an increase in self threshing among branches on a given plant. However, when wind and precipitation events were determined alone or in combination via multiple linear regressions, they did not appear to play a significant role in influencing seed shatter $\left(r^{2} \leq 0.05, \mathrm{P} \leq 0.001\right)$.
Aside from weather, other factors also likely influenced the rate of giant ragweed seed shatter. For example, there was evidence of birds, rodents, insects, and plant pathogens interacting with giant ragweed plants, and likely influencing rates of seed shatter. Several studies have found that 2 to $19 \%$ of giant ragweed seeds are infested by various insects (Amatangelo 1974; Harrison et al. 2001; Vitolo and Stiles 1987), and that taller, isolated giant ragweed plants attract and experience the most granivory from seed-feeding insects, which could have affected seed shatter (Abul-Fatih et al. 1979). Nearly all plants had stem-boring damage from insects, but there was no correlation with the rate of seed shatter. Complex combinations of weather, biological factors, and other environmental factors appear to ultimately influence giant ragweed seed retention.

Conclusions. Giant ragweed plants escaping earlyseason weed control strategies produce substantial amounts of seeds, providing the opportunity for escaped weeds to proliferate. Results from this study indicate that when adhering to a zero-weed threshold, there is a substantial window of time before seed development to remove giant ragweed plants from production fields and adjacent field margins to prevent seed bank replenishment. Giant ragweed seed production and retention were not directly affected by field location. Rather, field location primarily influenced the amount of competition with giant ragweed plants, which ultimately reduced total seed production but did not affect seed retention patterns, indicating that field margins may be managed similarly to soybean fields to prevent seed bank replenishment. Giant ragweed plants did show high seed retention rates through the harvest months in both soybean and field margins. Hard (potentially viable) seeds tended to shatter from plants at a higher rate than soft (nonviable) seeds, which both began shattering on September 12 on average and continued through October. Therefore, earlier harvest dates for soybean would provide increased potential to capture giant ragweed seeds if implementing HWSC mechanisms at harvest. Even with an average harvest date in Minnesota of October 8 (USDA-NASS 2010), 80\% of the hard (potentially viable) seeds are retained on giant ragweed, indicating that there is potential to capture giant ragweed seeds at crop harvest.

These results indicate that there is potential for HWSC to be effective against giant ragweed.

Goplen et al.: Giant ragweed seed retention • 251 
Because of the nature of harvesting equipment for crops common to the midwestern United States, HWSC mechanisms may only be effective in soybean, as the harvesting equipment has greater potential to feed weed biomass into the harvester than corn-harvesting equipment. The overall variation in seed retention of giant ragweed (Figure 1) suggests that it is highly likely that implementing HWSC would select for giant ragweed plants that shatter seeds earlier. However, if HWSC is used as part of an integrated weed management plan, these strategies have potential to control herbicideresistant giant ragweed. Overall, these results indicate that harvesting equipment is likely a primary mechanism of giant ragweed seed spread, since the majority $(>63 \%)$ of giant ragweed seeds are retained on plants through the end of October. To proactively manage giant ragweed, it will be important to consider the role that harvesting equipment has on mechanically spreading giant ragweed seeds both within fields and across agricultural regions, and how this spread can be minimized, especially when dealing with herbicideresistant biotypes.

\section{Acknowledgments}

This research was funded by the Monsanto Graduate Fellowship, the Torske Klubben Fellowship, and the Rapid Agricultural Response Fund of the Minnesota Agricultural Experiment Station. The authors also express appreciation to staff and students for their assistance, in particular Doug Miller and Brad Kincaid.

\section{Literature Cited}

Abul-Fati HA, Bazzaz FA, Hunt R (1979) The biology of Ambrosia trifida L. III. Growth and biomass allocation. New Phytol 83:829-838

Amatangelo J (1974) Infestation of seeds of Ambrosia trifida, giant ragweed, by larval insects. Bios 45:15-18

Ball DA, Miller SD (1989) A comparison of techniques for estimation of arable soil seedbanks and their relationship to weed flora. Weed Res 29:365-373

Barroso J, Navarrete L, Sánchez del Arco MJ, FernandezQuintanilla C, Lutman PJW, Perry NH, Hull RI (2006) Dispersal of Avena fatua and Avena sterilis patches by natural dissemination, soil tillage and combine harvesters. Weed Res 46:118-128

Bassett IJ, Crompton CW (1982) The biology of Canadian weeds. 55. Ambrosia trifida L. Can J Plant Sci 62:1002-1010
Baysinger JA, Sims BD (1992) Giant ragweed (Ambrosia trifida) control in soybean (Glycine max). Weed Technol 6:13-18

Blanco-Moreno JM, Chamorro L, Masalles RM, Recasens J, Sans FX (2004) Spatial distribution of Lolium rigidum seedlings following seed dispersal by combine harvesters. Weed Res 44:375-387

Brabham CB, Gerber CK, Johnson WG (2011) Fate of glyphosate-resistant giant ragweed (Ambrosia trifida) in the presence and absence of glyphosate. Weed Sci 59:506-511

Cardina J, Sparrow DH (1996) A comparison of methods to predict weed seedling populations from the soil seedbank. Weed Sci 44:46-51

Fenner M (1995) Ecology of seed banks. Pages 507-528 in Kigel J and Galili G, eds. Seed Development and Germination. New York: Marcel Dekker

Forcella F (1992) Prediction of weed seedling densities from buried seed reserves. Weed Res 32:29-38

Harrison SK, Regnier EE, Schmoll JT, Webb JE (2001) Competition and fecundity of giant ragweed in corn. Weed Sci 49:224-229

Heap I (2015) The International Survey of Herbicide Resistant Weeds. http://www.weedscience.org. Accessed March 16, 2015

Jurik TW (1991) Population distributions of plant size and light environment of giant ragweed (Ambrosia trifida L.) at three densities. Oecologia 87:539-550

Mann LK (1942) Effects of photoperiod on sex expression in Ambrosia trifida. Bot Gaz 103:780-787

Norsworthy JK, Griffith G, Griffin T, Bagavathiannan M, Gbur EE (2014) In-field movement of glyphosate-resistant Palmer amaranth (Amaranthus palmeri) and its impact on cotton lint yield: evidence supporting a zero-threshold strategy. Weed Sci 62:237-249

Page MJ, Newlands L, Eales J (2002) Effectiveness of three seedtrap designs. Aust J Bot 50:587-594

Rew LJ, Froud-Williams RJ, Boatman ND (1996) Dispersal of Bromus sterilis and Anthriscus sylvestris seed within arable field margins. Agric Ecosyst Environ 59:107-114

Shaner DL, Beckie HJ (2014) The future of weed control and technology. Pest Manag Sci 70:1329-1339

Shirtliffe SJ, Entz MH (2005) Chaff collection reduces seed dispersal of wild oat (Avena fatua) by a combine harvester. Weed Sci 53:465-470

Shirtliffe SJ, Entz MH, Van Acker RC (2000) Avena fatua development and seed shatter as related to thermal time. Weed Sci 48:555-560

Stoller EW, Harrison SK, Wax LM, Regnier EE, Nafziger ED (1987) Weed interference in soybeans (Glycine max). Rev Weed Sci 3:155-181

Taghizadeh MS, Nicolas ME, Cousens RD (2012) Effects of relative emergence time and water deficit on the timing of fruit dispersal in Raphanus raphanistrum L. Crop Pasture Sci 63:1018-1025

[USDA-NASS] U.S. Department of Agriculture National Agriculture Statistics Service (2010) Field Crops Usual Planting and Harvesting Dates (October 2010). Washington, DC: U.S. Department of Agriculture. p 41

[USDA-NASS] U.S. Department of Agriculture National Agriculture Statistics Service (2014) Minnesota Crop Progress. 
http://www.nass.usda.gov/Statistics_by_State/Minnesota/ Publications/Crop_Progress_\&_Condition/. Accessed December 14,2014

Vitolo DB, Stiles EW (1987) The effect of density of Ambrosia trifida L. on seed predation by Euaresta festiva (Loew) (Dipera: Tephritidae). J N Y Entomol Soc 95:491-494

Walsh MJ, Harrington RB, Powles SB (2012) Harrington seed destructor: a new nonchemical weed control tool for global grain crops. Crop Sci 52:1343-1347

Walsh MJ, Newman P (2007) Burning narrow windrows for weed seed destruction. Field Crop Res 104:24-30

Walsh MJ, Newman P, Powles SB (2013) Targeting weed seeds in-crop: a new weed control paradigm for global agriculture. Weed Technol 27:431-436
Walsh MJ, Powles SB (2007) Management strategies for herbicide-resistant weed populations in Australian dryland crop production systems. Weed Technol 21:332-338

Walsh MJ, Powles SB (2014) High seed retention at maturity of annual weeds infesting crop fields highlights the potential for harvest weed seed control. Weed Technol 28:486-493

Webster TM, Loux MM, Regnier EE, Harrison SK (1994) Giant ragweed (Ambrosia trifida) canopy architecture and interference studies in soybean (Glycine max). Weed Technol 8:559564

Received July 23, 2015, and approved October 4, 2015.

Associate Editor for this paper: Lawrence Steckel, University of Tennessee. 